УДК 328.327.323

DOI https://doi.org/10.32837/apfs.v0i28.948

Ю.Р. Лемко

ORCID ID: https://orcid.org/0000-0002-9864-6963

кандидат політичних наук,

асистент кафедри політологї̈ та міжнародних відносин

Національного університету «Львівська політехніка»

\title{
КЛАСТЕРИ ЯК ОДИН З ІНСТРУМЕНТІВ ФОРМУВАННЯ ПОЛІТИКИ СУСІДСТВА ЄС
}

Кластерна політика $€ \mathrm{C}$ почала формуватися в кінці 90-х pp. ХХ ст. На початку кластери являли собою «скупчення» підприємств і фірм, які вважали вигідним своє розташування в географічній близькості один до одного з метою економії на витратах під час транспортування ресурсів і комплектуючих для створення кінцевого продукту. Згодом 3'ясувалося, що стратегічно вигідною $€$ наявність у безпосередній близькості установ, що здійснюють наукові розробки. Таким чином, ще у вісімдесяті роки в Західній Європі було виявлено ключовий принцип кластерного підходу - тісну взаємодію виробничих фірм і наукового середовища. Потім цей взаємозв'язок бізнесу та науки був доповнений взаємодією 3 місцевими органами державної влади, які оцінили перспективність кластерного підходу і почали надавати кластерам істотну підтримку.

Процеси кластеризації в останнє десятиліття активно досліджують такі вітчизняні науковці, як Л. Антонюк, Н. Блажевич, О. Варяниченко, М. Войнаренко, Н. Внукова, В. Геєць, В. Демченко, В. Дергачова, В. Захарченко. Водночас недостатньо вивченими є формоутворюючі процеси кластеризації в Європейському Союзі та їх адаптація до умов національних економік.

Все вищезазначене зумовило вибір теми, визначення мети та завдань дослідження.

Метою статті є дослідження історії зародження кластерної політики ЄС та їі особливостей на сучасному етапі розвитку держав.

Виклад основного матеріалу. Окремі країни ЄC реалізують кластерну політику (КП) починаючи з 1990-х рр. За період розвитку таких ініціатив на національному рівні з'явилися передумови для інституціоналізації процесу розвитку кластерів на наднаціональному рівні.

Державна кластерна політика (далі - КП) - це новий спосіб організації економічної політики в країні за участю нових об'єктів - просторових і позапросторових кластерів [3].

За визначенням Єврокомісії, кластери (залежно від специфіки можуть вживатися також словосполучення «промислові кластери» або «інноваційні кластери») - це групи спеціалізованих організацій, переважно малих і середніх підприемств (МСП), та інших акторів, які тісно взаємодіють один з одним на окремо взятій території [2].

Об'єднуючись, МСП можуть бути більш інноваційними, створювати більше робочих місць і більше конкурентоспроможних на світовому рівні продуктів, торгових знаків і патентів, ніж поодинці. Прикладами промислових кластерів є Авіаційна долина на південному сході Польщі, яка об'єднувала у 2019 р. понад 140 компаній та організацій з аерокосмічної галузі [1]. Також до прикладів можемо віднести Авіаційну долину у Франції, яка об'єднує понад 860 організацій, 3 яких 575 - МСП з Баварії та Ломбардії (Італія, 127 підприємств). У кластерах, число яких в Європі перевищило 3000 , сконцентровано близько 54 млн європейських робочих місць [2].

У 2003 р. групою авторів, включаючи О. Солвелля, Г. Ліндквіста (Стокгольмська школа економіки), К. Кетельса (Гарвардська бізнес-школа, колега М. Портера), була сформована «Зелена книга кластерних ініціатив», у якій проведений всебічний аналіз близько 250 програм по всьому світу і запропонована модель оцінки їх роботи (Cluster Initiative Performance Model) [7].

Після цього група авторів з Лондонського університету створила «Білу книгу кластерної політики» 3 фокусом на те, який вигляд повинна мати КП [6].

У 2007 р була заснована Європейська кластерна обсерваторія (далі - Обсерваторія). Центр стратегії і конкурентоспроможності Стокгольмської школи економіки, очолюваний О. Солвеллем i Р. Тайгланд, став здійснювати управління Обсерваторією і вести збір статистичних даних. У результаті була запропонована оновлена версія «Зеленої книги кластерних ініціатив», яка вийшла в 2013 р. з аналізом 356 організацій у 50 країнах світу [7]. Багато в чому в «зеленій» і «білій» книгах акцент зроблений на позитивних сторонах кластерного розвитку. В результаті кластерний підхід був підтриманий на наднаціональному рівні, і такого роду організації (інститути, що забезпечують координаційну функцію в рамках кластера) отримали доступ до підтримки спеціалізованих інститутів.

Проте в програмних документах Європейської комісії і Ради ЄС кластери були визначе- 
ні як ефективний засіб посилення регіональних інновацій та скорочення розриву між бізнесом, дослідженнями та ресурсами, а також увійшли до програм регіональної політики ЄС на період 2007-2013 pp. [2].

Експерти ЄС вважають, що вони не є єдиною обов'язковою умовою для стимулювання інноваційної діяльності, але покликані створювати рамкові умови для більш швидкого застосування і поширення результатів інноваційної діяльності.

Сучасна промислова політика ЄС грунтується на просуванні конкурентоспроможності європейської промисловості через реалізацію ряду ключових ініціатив: розвиток необхідних навичок i компетенцій для промисловості, пожвавлення регіонів шляхом розвитку кластерів і платформи розумної спеціалізації, підтримка цифрової трансформації галузей, розробка ключових високоефективних технологій і просування стандартів IКT1. Таким чином, для Європейської комісії КП є складовою частиною промислової політики.

Рада ЄС у висновку про стратегії промислової політики СС у 2018 р також наголосила на необхідності подальшого розвитку КП Євросоюзу з метою з'єднання і трансформації регіональних кластерів у загальноєвропейські і виникнення нових ланцюжків вартості [1].

При цьому в науковій (і не тільки) літературі все частіше говорять про нову промислову політику, яка спрямована не на управління економікою «зверху вниз», а на сприяння її кластеризації методом «знизу», заохочуючи масові мережеві взаємодії і відповідні ініціативи [3].

Одним з основних критеріїв нового підходу є відмова від підтримки державою цілих секторів економіки на користь переходу до підтримки окремих напрямів діяльності (наприклад, замість загальних субсидій для туристичної галузі субсидувати створення спеціальної інфраструктури) [2]. У зв'язку з цим «КП ЄС - це частина промислової політики, яка не спрямована на створення «3 нуля» самих кластерів, а фокусується на формуванні «умов для діалогу і співпраці між компаніями, державним сектором (локальним / регіональним) і недержавними організаціями» [1].

Для підтримки діалогу та співпраці в ЄС протягом останніх десятиліть формувалися інститути КП, які виконують в основному функцію координації, збору інформації, навчання та сприяння у фінансуванні учасників кластерів або їх виходу на міжнародні ринки.

Важливе місце у формуванні єдиного загальноєвропейського підходу до КП займають окремі інститути підтримки - одним з перших стала згадана вище Кластерна обсерваторія. Вона дозволила об’єднати інформацію про існуючі кластери, кластерні ініціативи і політику 36 країн Європи і класифікувати їх за різними параметрами, вклю- чаючи економічні індикатори діяльності окремих регіонів і секторів економіки.

Крім консолідації інформації в рамках Обсерваторії, з 2009 по 2012 р. проводилось вироблення методології для відбору кращих практик серед європейських кластерів - European Cluster Excellence Initiative (ECEI). Ключова мета ініціативи полягала в розробці методології бенчмаркінгу (порівняльного еталонного аналізу) таких організацій для поліпшення їх внутрішнього управління та процесу надання послуг. Після 2012 р. завдання ECEI перейшли до Європейського секретаріату кластерного аналізу (European Secretariat for Cluster Analysis) і Європейського фонду висококласних кластерів (European Foundation for Cluster Excellence), які продовжують здійснювати їх бенчмаркінг на постійній основі, проводити спеціальне навчання для керівників цих організацій.

3 метою розвитку міжнародного співробітництва між ними була створена Європейська платформа кластерної співпраці. Більше 1000 зареєстрованих на платформі кластерних організацій з Європи та інших точок світу мають можливість зіставляти результати своєї діяльності з іншими, брати участь у спеціальних програмах, що дозволяють встановлювати взаємовигідні ділові зв'язки з необхідними партнерами.

Згідно з виконавчим рішенням Свропейської комісії серед загального обсягу фінансових коштів у розмірі 397,6 млн євро, виділених на програму OSME (Програма конкурентоспроможності, підприємництва та МСП), в 2018 р. 5,9 млн євро було розподілено на «створення оновленої ЕССР, яка стане основним онлайн-хабом для учасників кластерів у Європі через об'єднання Європейської обсерваторії для кластерів і Свропейського центру знань з ресурсної ефективності» [1]. У сукупності зазначені ініціативи і платформи охоплюють спектр інструментів, необхідних для координації КП і розвитку окремо взятих МСП або проєктів - від збору інформації до допомоги у виході європейських підприємств на світові ринки. Не всі організації збереглися в своєму первинному вигляді, що говорить про еволюційний характер інститутів кластерного розвитку в ЄС і підходів до реалізації КП загалом.

Таким чином, європейський підхід до розвитку цієї сфери і створення інститутів її підтримки досить послідовний. Умовно процес реалізації наднаціональної КП в СС можна розділити на чотири фази [7], до яких слід додати п'яту:

1. Фаза 1 (2000-2006 рр.) - Сврокомісія почала проводити різні пілотні ініціативи з підтримки кластерів в ЦСЄ через програму PHARE.

2. Фаза 2 (2007-2009 рр.) - підписання Свропейського кластерного меморандуму, створення кластерних обсерваторій, розробка інформаційноаналітичних матеріалів. 
3. Фаза 3 (2010-2012 рр.) - фокус на підвищення якості кластерних програм, створення інструментів оцінки та ранжування, підготовка «кластерних управлінців».

4. Фаза 4 (2013-2017рр.) - інтеграція кластерів у регіональні програми через принцип «розумної спеціалізації» для сприяння структурним змінам паралельно з розвитком сильних сторін регіонів.

5. Фаза 5 (2017 - поточний час) - кластери як об'єкти нової промислової політики ЄС, розвиток і зміцнення кластерних інститутів, створення робочої групи по кластерах.

Остання фаза характеризується завершенням семирічного циклу бюджетного плану до 2020 року, до якого прив'язана велика частина програм, і необхідністю формування нового бачення пріоритетів економічного розвитку і узгодження бюджету на 2021-2027 pp.

$\mathrm{y}$ повідомленні про новий довгостроковий бюджетний цикл ЄC (2021-2027 рр.) у рамках програми «Єдиний ринок» кластери згадуються як «стратегічний інструмент для підтримки конкурентоспроможності та масштабування МСП, тому що формують більш сприятливе середовище для ведення підприємницької діяльності» [7]. Загальний, запропонований до утвердження обсяг фінансування програми «Єдиний ринок» становить 4 млрд євро, з яких 1 млрд євро буде спрямовано на програму COSME, використовувану в тому числі для фінансування інститутів по їх розвитку.

У документі «Стратегія оновленої промислової політики ЄС» від 2017 р. (СОМ (2017) 479 final) відзначено створення експертної групи високого рівня по кластерах для надання рекомендацій про те, «як краще використовувати ї як стратегічний інструмент промислової політики». Фактично така група була створена в середині 2019 року (Е03636) під егідою Генерального директорату з внутрішнього ринку, промисловості, підприємництва, малого і середньому бізнесу 3 терміном до кінця 2020 p. Вона об'єднує 32 незалежних експерта та представника органів влади країн - учасниць ЄС.

Крім того, кластерам відведена особлива роль у веденні промисловості ЄС до 2030 р. Промислові кластери розглядаються як фундамент екосистеми, що сприяє інноваційній та технологічній активності. В рамках заходів щодо прискорення процесів цифровізації також планується формування «суперкластера» 3 наукомісткими стартапами в сфері штучного інтелекту (Deep Tech AI). Таким способом $\mathrm{CC}$ прагне зберегти свою конкурентоспроможність, приділяючи значну увагу розвитку інновацій, включаючи загальну цифровізацію економіки. У документі згадується програма «Кластери змін», спрямована на підтримку нового покоління мереж, які створюють вартість та будуть відкритими та міжсекторально націленими на реалізацію «Цілей сталого розвитку», взаємопов'язаними, стимульованими підприємницькою активністю [7].

Як майданчик для обміну думками щодо стану та перспектив реалізації КП вже четвертий раз поспіль (три зустрічі в 2018 р і одна в 2019 р.) використовується Форум європейської КП (далі Форум). Основний акцент у рамках останнього Форуму був зроблений на міжнародному співробітництві та допомоги у виході МСП, які беруть участь в кластерах, на світовий ринок [4].

Висновки. Отже, проведений аналіз показав, що кластерна політика ЄС входить як одна зі складових частин в нову промислову політику, спрямовану на підтримку інноваційної активності і технологічного розвитку. У своїх програмних документах Єврокомісія не раз відзначала потенціал кластерів у частині формування сприятливих інноваційних регіональних екосистем для взаємного посилення груп МСП. Основна увага приділяється не тільки промисловому сектору, а й міжсекторальному та транскордонному співробітництву та інноваційній діяльності. Слід зазначити, що КП в ЄС не розглядається як єдиний, уніфікований документ для всіх країн-членів, проте $€$ набором кращих / хороших практик, підходів, ініціатив та рекомендацій як для представників такого роду організацій, так і для національних і регіональних органів влади.

За відсутності уніфікованої системи є і певні мінуси. Вони пов'язані з різноманіттям тлумачень i вживань терміна «кластер», відсутністю розуміння самими компаніями явних плюсів від підтримки з боку інституцій $\mathrm{CC}$ та участі в їх ініціативах (це підкреслювалося на останньому Форумі). Переосмислення накопиченого досвіду з реалізації КП перед початком наступного бюджетного циклу 2021-2027 pр. бачиться як правильна міра, яка дозволить уникнути фінансування програм, які не показали достатньої результативності, i створення нових інститутів без особливої необхідності. Досвід ЄС у частині підтримки кластерів актуальний i для інших держав, які прагнуть стимулювати свій інноваційний розвиток.

\section{Jimepamypa}

1. Офіційний сайт Європейської платформи по кластерному співробітництву. URL: https://www. clustercollaboration.eu/.

2. Офіційний сайт кластерної політики Європейської комісії. URL: https://ec.europa.eu/growth/ industry/policy/cluster_en/

3. Пилипенко И.В. Новая геоэкономическая модель развития страны: повышение конкурентоспособности с помощью развития кластеров и промышленных районов. Безопасность Евразии. 2003. № 3. C. 580-604. 
4. Результати 3-го Форуму європейської кластерної політики. URL: https://ec.europa.eu/growth/content/ third-european-cluster-policy-forum-improvinglinkages-and-synergies-cluster-policy_sl

5. Циренщиков В.С. (2019) Цифровизация экономики Европы, Современная Европа. № 3. С. 104-113.

6. Andersson T., Schwaag-Serger S., Sörvik J., Wise E. (2004) Cluster Policies Whitebook. IKED International Organization for Knowledge Economy and Enterprise Development.

7. Commission proposal for a Regulation of the European Parliament and of the Council establishing the Programme for single market, competitiveness of enterprises, including small and medium-sized enterprises, and European statistics and repealing Regulations (EU) No 99/2013, (EU) No 1287/2013, (EU) No $254 / 2014$, (EU) No $258 / 2014$, (EU) No $652 / 2014$ and (EU) $2017 / 826 \mathrm{COM}(2018) 441$ final of 7.06.2018. Available from: https://eur-lex.europa.eu/legal-content/ $\mathrm{EN} / \mathrm{TXT} /$ ?uri=CELEX $\%$ 3A52018PC0441

8. The Cluster Initiative Greenbook. Ö Sölvell, G Lindqvist, C Ketels. Ivory Tower, 2003.

\section{Анотація}

Лемко Ю.Р. Кластери як один з інструментів формування політики сусідства ЄС. - Стаття.

$\mathrm{V}$ цій статті розглянуто один із складників європейської політики сусідства, а саме кластерну політику в контексті транскордонного співробітництва. Загальновідомо, що ТКС співробітництво в умовах розвитку інтеграційних процесів має властивість прискорювати процеси вирівнювання якості життя населення прикордонних територій, доводити її до середньоєвропейського рівня та сприяти досягненню вільного переміщення товарів, капіталів і людей через кордон. Воно забезпечує мобілізацію місцевих ресурсів та підвищення ефективності їх використання, робить можливим об'єднання зусиль для вирішення спільних проблем у транскордонному регіоні. Транскордонне співробітництво відіграє важливу роль як «полігон» для випробовування та адаптації європейського законодавства, інструментарію підвищення ролі регіонів, адаптації механізмів фінансової підтримки. Методологічною основою розвитку транскордонного співробітництва стала теорія постіндустріального суспільства, парадигмою якої є пріоритет людини, її творчий та інтелектуальний потенціал, умови її життєдіяльності. На сучасному етапі відбувається трансформація у напряму формування постіндустріального суспільства, яке базується на взаємодії між людьми, а отже - на співпраці та спільній діяльності людей, спрямованій на вирішення окремих завдань.

У цій статті розглянуто один із інструментів формування політики співробітництва Європейського Союзу, а саме кластери. В контексті розвитку нашої держави та $з$ огляду на її подальший інтеграційний вектор, вважаємо це дослідження актуальним та доцільним. Зазначається, що кластерна система становить частину нової промислової політики ЄС, спрямованої на підвищення конкурентоспроможності європейських компаній на світовому рівні. У статті досліджується, як саме кластери служать необхідною інфраструктурою, точкою збірки безлічі ініціатив, які потребують залучення груп учасників з боку держави, бізнесу і науково-дослідницького співтовариства, а також платформою для подальшого посилення міжрегіонального співробітництва та тіснішої інтеграції. У статті надано огляд еволюції інститутів кластерної політики, створених на наднаціональному рівні в ЄС, на основі програмних документів Сврокомісії та ініціатив ряду країн-членів. Розглянуто перспективи подальшої реалізації кластерної політики ЄС з урахуванням запропонованих ініціатив у рамках нового бюджетного циклу.

Ключові слова: транскордонне співробітництво, кластери, ЄС, політика сусідства ЄС.

\section{Summary}

Lemko Yu.R. Clusters as one of the tools for formation of cooperation policy in the EU. - Article.

Cross-border cooperation in the development of integration processes has the ability to accelerate the process of equalizing the quality of life of the population of border areas, bring it to the average European level and promote the free movement of goods, capital and people across the border. It mobilizes local resources and increases the efficiency of their use, makes it possible to join forces to solve common problems in the cross-border region. Cross-border cooperation plays an important role as a "testing ground" for testing and adaptation of European legislation, tools for enhancing the role of regions, adaptation of financial support mechanisms. The methodological basis for the development of cross-border cooperation was the theory of post-industrial society, the paradigm of which is the priority of man, his creative and intellectual potential, the conditions of his life. At the present stage, there is a transformation in the direction of forming a post-industrial society, which is based on interaction between people, and hence - on cooperation - the joint activities of people aimed at solving certain problems. This article considers one of the tools for shaping the policy of cooperation of the European Union, namely clusters. In the context of the development of our state and taking into account the further integration vector, we consider this study relevant and appropriate. It is noted that the cluster system is part of the new EU industrial policy aimed at increasing the competitiveness of European companies at the global level. The aim of the article is to explore how clusters serve as the necessary infrastructure, a collection point for many initiatives that require the involvement of groups of participants from the state, business and research community, as well as a platform for further strengthening interregional cooperation and closer integration. The article provides an overview of the evolution of cluster policy institutions created at the supranational level in the EU, based on the European Commission's policy documents and initiatives of a number of member states. Prospects for further implementation of EU cluster policy are considered, taking into account the proposed initiatives within the new budget cycle.

Key words: cross-border cooperation, clusters, EU, EU neighborhood policy. 